\title{
Nista Madya Utama, The Local Wisdom to Achieve Prosperity and Peace in the Digital Era
}

\author{
S H Widyastuti \\ \{sriharti@uny.ac.id \} \\ Yogyakarta State University Yogyakarta, Indonesia
}

\begin{abstract}
Cultural change that has triggered various problems in people's lives in the industrial revolution era 4.0 raises many problems, in order to overcome them, appropriate local wisdom is needed. This study was aimed at describing the main concept nista madya utama as a local wisdom for leaders and for world peace throughout the ages. The theory used was modern and hermeneutic philology theory. The method used in this study was descriptive method. The main concept of nista madya utama originates from Javanese local wisdom which means to abandon evil deeds, having high moral standard or in middle level for people with dissabilities. These concepts are very suitable for leaders, because the Javanese leader is like a king, so that controlling nista madya utama will have an impact on the peace of the people. This local wisdom applies throughout the ages in any era. So called because the concept of acting according to ability, avoiding bad deeds and doing virtue in life is a concept that can be a controller in any era. The main concept of nista madya utama is able to memayu hayuning bawana or maintain the safety of the earth and its contents and memayu hayuning family that is maintaining the integrity of the family.
\end{abstract}

Keywords: Nista Madya Utama, Local Wisdom, Digital Era

\section{INTRODUCTION}

Indonesia is currently experiencing a new round, namely the post-election round in the era of modern society. Besides that, the community is being denounced with digital facilities in life. This situation causes people to be easily influenced to do bad things. Machiavelly mentions that political life is clearly marked by the existence of power anarchy and moral decline in the relations of government of a country [1].

People are confused by various statements from officials and community leaders. Even people are tested for their maturity to be able to behave. Society is made resistant as well as Hobbes's philosophy which states that basically everyone will serve his own interests first and ignore the interests of others [1]. The confusing chaos is happening nowadays because among groups are more concerned with their interests than the interests of other groups or communities so that there is a mutual struggle for digital power to be able to win the sympathy of the community.

In that position, power becomes the field to reach office and property which sometimes uses methods that show other interests. In this case the desire to achieve something becomes wild without being aware of the nature of life that must maintain harmony. The role of religious leaders, religious teachers and pastors is very big to be able to make people aware 
that they are not excessive and return to normal lines. Even the condition of the community seems to be a trigger for some people to be industrious to worship to calm themselves and return to their shari'a.

Javanese society as a very old cultural community [2] is a community that has a wealth of local wisdom. Local wisdom is powerful enough to make the Javanese community resistant to various suffering of colonialism, politics of divide et impera, and the overthrow of democracy. History writes that the Javanese people will experience a deranged era. This was stated in the Jayabaya Term forecast. At that time it was mentioned that all bad behaviors carried out by humans even mentioned people who did not follow to do bad things, then he would not benefit. In Javanese society even life's irregularities are referred to as crazy ages [3].

To overcome the enormous conditions of cultural change, one of the things that can be used as a moral and social controller is local wisdom. That is because local wisdom is a cultural result. An ancestral heritage is a source of traditional knowledge and virtues that ancestors have done in their time. local wisdom contains moral teachings in order to have selfcontrol over improper behavior.

One of Javanese local wisdom that is quite well known is the moral teaching that became the view of life of leaders in the past. The concept is hereditary taught by kings to their descent. The concept is divided into nista, madya and utama. This concept evolved from thinking which was later discovered orally from generation to generation. Therefore, this concept is often included as tradition and folklore. Folklore is a hereditary habit produced by certain groups of people [4].

Folklore is distinguished by verbal (oral), semi-verbal, non-verbal. The folklores which are included in oral folklore are those which spread orally and are found in oral form [4]. Oral folklore develops from oral stories that are purely oral or can also be written literatures which are then passed down orally from generation to generation so that they experience considerable variation. Therefore, the main concept of civil society which is the result of verbal folklore is actually the work of Javanese literature. Javanese literary works which contain this concept develop and experience meaning according to the mimetic recipient of this concept. The main concept of nista madya utama becomes a concept which is at the same time a view of life in Javanese culture which contains a role as a balancer of life while also controlling behavior.

Based on this understanding, it appears that the main concept ofnista madya utama originates from Javanese local wisdom that is important for people's lives, especially for a leader. This concept contains values which develop into traditional expressions which are subconcepts of the nista madya utama. Cultural changes that cause various household and community problems.

If this concept is implemented in a row of government and household leadership, it will be able to control the turmoil of cultural change. As a result, the situation becomes more conducive, and peaceful. The concept of nista madya utama as part of Javanese local wisdom is as the control of individual moral. This is then considered effective as moral teachings that are controlling actions.

\section{RESERACH METHOD}

The main concept of nista madya utama in this paper is based on Javanese literary text entitled Serat Aji Pamasa and Serat Wulang P.B. IX. Serat Aji Pamasa is written by the famous one, R. Ng. Ranggawarsita. While Serat Wulang P.B IX are literary works consisting of various serats which are the work of Paku Buwana IX. The main data source of the main 
concept of nista madya utama described is Wulang P. B IX in the form of manuscripts. The modern philological theory was used to analyzed the manuscrips while hermeneutics was used to analyzed the meaning contained in. The method used was modern and descriptive philology method. The modern method of philology was done by transliteration and translation.

\section{RESULT AND DISCUSSION}

The concept of nista, madya, and utama is the teaching contained in Serat Nitipraja. Serat Nitipraja is the work of Sultan Agung. Therefore, the view of the nista madya utama is the teaching developed by Sultan Agung. Besides that, this teaching also found in Serat Aji Pamasa by R.Ng Ranggawarsita and in Cetha Literature. Serat Nitipraja has the same text with Serat Niti Sruti and Jayabaya [5]. The main concept of nista madya utama is also explained in Serat Wulang P.B. IX and become a life view of Susuhunan Paku Buwana IX. Below is a description of these concepts.

\subsection{The concepts of Nista}

Nista means low, trivial for behavior [6]. Mischief is a very bad act, even religious prohibition. Nista deeds are despicable acts [7]. In Serat Wulang by P.B. IX, mentioned an act of contempt which is when a woman or estri turns to another man. Likewise the actions of women who are dishonest, lying, not accepting sincerely their husbands' giving, often angry, not filial, brave, not appreciative, and presumptuous to their husbands are the examples of despicable actions (Serat Wulang, pupuh 38, verse 1-7). Above are nista concepts for a woman who is married.

Paku Buwana IX states that people who continue to commit abusive acts will eventually find it difficult to distinguish between despicable and non-despicable actions (Serat Wulang P.B. IX, pupuh 44, verse 2). In Serat Nitipraja, it is stated that nista acts are actions that harm other people, the community, or the people in a country [8].

In government environment, it is detrimental to the people, denying the mandate, expecting something to be done not because of their responsibility, but because they want to get profits and wages. Further mentioned in Serat Aji Pamasa that if a king has the nature of wanting to own property belonging to the people or retainer, even if by buying. Then if the owner is not happy, the intention should be undone [8].

In Cetha Literature, it is stated that the character of Rama teaches Bharata that someone in evil deeds are always worried in all things, has not firm in mind, put prejudice on relatives and officials, government and always have doubt [9]. Nista actions are human actions that want to have the rights of others in a wrong way. Greedy and lustful attitude to have something by endanger others is an act of nista. The insulting concept for the servants of the state was conveyed by Ajar Surabasata to his son named Sasana.

The concept of nista is caused by the attitude or wishy-washy plan, bandha sumitra or other people's property, rules of regulation or complaining of other people's ugliness, makoleh ken awak or personal selfishness, sakutha batin which is in the mind feeling the king's trust or leader, datan anetepi or disobey, and iren-irenan or jealous envy [10].

In the text of Serat Wulang P.B. IX stated that living humans are welcome to choose. Humans can choose to do virtue or evil. Signs of goodness and meanness are arranged and written in the books. As for what needs to be avoided is to do a lot of nista behaviors. Nista behavior is low behavior and can cause a variety of adverse consequences as stated in the text excerpt of Serat Wulang P.B. IX, pupuh 38, verse 2 as below. 
Kang kalaku/ madya utama kapungkur/ nista ingkang kathah/ tata nista karma nistip/ ardada rangka ardami/ ngombra-ombra//

What is often done / is forgetting madya and utama behavior / doing a lot of nista / nista behavior is / low behavior / and it is growing //

\subsection{Concepts of Madya}

The definition of madya is middle or medium. Madya as part of the main concept of nista madya utama which means being in the middle or the right one. The madya concept is a concept whose implications are in the form of non-deviant actions, in this case following the norms, rules, and legislation. In everyday life, the concept of madya is identical to carrying out orders from superiors, can curb lust, not act badly, and does not have the intention to harm and make other people lose. Likewise, the madya concept leads to the giving of things and obligations in the context of their responsibilities. Madya deed is the act of avoiding evil deeds. Madya or middle nature is a trait that is in the middle between the nista and the utama. Intermediate behavior is behavior as it is.

In Serat Aji Pamasa, it is stated that if a king has a generous nature, then there are people who are deficient to come to the king to ask for help, then the king is obliged to provide sufficient funds to meet their needs. The king could have refused the request if he felt the king had spent too much money. If there is someone who presents valuable items to the king, then the king is obliged to provide valuable rewards as a substitute. In this case the intermediate nature is the nature that carefully considers everything well. The middle concept for the servants of the state is delivered by Ajar Surabasata to his son named the Sasana. According to him the cause of the emergence of madya act is taberi or diligent, anggugu or obedience, and mituhu or heed. Likewise can be guided or can be responsive to problems.

The madya concept is almost the same as the concept of narima ing pandum which is accepting what is, wedi ing pepaco or fear of prohibition, bisa angon ing wahyaning mangsakala or can adjust according to situations and conditions [10]. This madya concept is a concept that shows the local wisdom of Javanese people, where there is flexibility in behaving in life. This middle attitude, it shows the teachings that a person must be able to measure himself, no need to overdo it. People who cannot measure their own abilities and are too excessive aiming for praise. This person can be called a blaba wuda or someone who does not think of abilities so that all his possessions are given to others. As a result, he himself suffers from lack or even no ability at all. This madya concept is also relevant to the concept of caution.

\subsection{Concepts of Utama}

The concept of Utama is the concept that leads to the main actions or very good level of act. These actions will make other people happy. The utama action requires efforts that are more than just intermediate actions in order to provide more benefits to the community. The actions of utama are usually actions that are followed by the desire to do good and do service so that the community is avoided from the suffering situation. The actions usually require sacrifice. The action is seen in people who sincerely want to share for others, the poor, orphans and the people in general who suffer. The concept of utama is part of the nista madya utama concept of civil society in Serat Wulang P.B. IX emphasized that the king would take the lead in carrying out his obligations and life. This can be seen in the quote text Serat Wulang pupuh 4 verse 15 below. 
Dadiya jayeng jaya nung/ wenang amengku mumpuni/ mring manungsa kang widadal darsaneng praja utami/ mulus tulusa utama/ sedyane ingkang marsudi//

Be a superior person/ who has great power/ in sustainable Javanese land/ as an example of the superior/ flawless government/ such desires are expected//

In the text, it is stated that the main human being is king, where the king has great power. In the government there are no gaps and vices that the people live in a safe, peaceful and peaceful life. It is stated that parents or ancestors taught examples from their ancestors which could be classified as middle and primary actions. As in the quote Serat Wulang pupuh 20 verse 2 .

\section{Rama ibu/ ambabar tuladanipun/ leluhur ing kuna/ kang nista madya utami/ sayogyane piniliha kang utama// \\ Mother and father/ tell the story of the example/ the ancestors in ancient times/ about the nista madya and utama/ should choose the utama one//}

In the text, it appears that the kings should choose the utama actions in order to carry out their duties. The utama concept leads a king to have a virtuous nature to take it like one who has a sincere, sincere feeling, likes to give funds or alms to others. For people who undergo the main practice, will make the heart to be holy, clean, firm and steadfast in its establishment. To take the utama action is not easy. The person must not be easily shaken up, able to distinguish lies, act wisely, not harm other parties, be humble, not arrogant, gentle and always want to increase knowledge. The utama attitude is also shown by the ambeg paramarta attitude so that it will be patient and compassionate. And give forgiveness to those who have been guilty of him [10].

In everyday life the utama attitude is a commendable attitude. It is stated that the utama attitude comes from the tranquility of the mind. For a servant of the state, there are 7 utama attitudes that must be done so that the work is of prime value, namely (1) temen or sincerity, (2) gemi or economical, (3) nastiti or careful, (4) ngati-ati or being careful , (5) angrawruhi or give knowledge and provide explanations if other people do not know, (6) santosaning kalbu or heartiness, and (7) mantep or steady. The concept was conveyed by Ajar Sarabasata to his son Sang Sasana [10]. The utama characteristic is the characteristic that is an example for employees. This can be seen in Serat Wulang P.B. IX pupuh 33 verse 3, as below.

Kongas budine tan angas/ ngulama adoh mring melik/ yaiku mantri prawira/ dadi tuladhaning mantri/ kang seja mamrih becik/ mangkono labuhanipun/ sumingkir mring kanistan/ angayunaken utami/ mardi basa basukaning saniswarall

Very well-known behavior that is not only limited to mere talk and not a coward/ good and not jealous/ so employees who have the utama character/ become an example for other employees / who intend to have the main traits/ stay away from bad behavior/ expect virtue for everything that is utama // 
In the text, it is shown that the utama behavior refers to people who are not only good at talking but also good at doing things. The person is not a coward, in his heart there is never jealousy. The utama employee will usually be a role model for other employees. Likewise the utama nature must be able to defeat the act of contempt. In his behavior, he must look for everything in the first place. In royal ethics the utama action is to prioritize God's interests from personal interests. Similarly, the person did not violate the king's prohibition or Illahiyah law. When compared with madya actions, the madya action is more to set aside personal interests and prioritize common interests. Not violating state rules. While the act of nista is an act that should not be done. This madya concept will be very good if done by people who have the ability, that is a person with a high social class. This means that the person has the freedom of funds so that those people will easily be able to spend some of their wealth to help others / this action is the utama action associated with giving to others.

\subsection{The concept of Nista Madya Utama, Javanese local wisdom for leaders}

The concept of nista madya utama was originally developed as local wisdom which was used as advice to a leader in order to lead well and the people to be peaceful and peaceful. Likewise, this local wisdom is the fruit of the thought of the position of the king as the ruler on earth or the King God. Deity of the king is one concept that originates from the understanding of the king is khalifatullah. Khalifatullah is the vicegerent of Allah. Khalifah or khalafah comes from the word khallaf which means behind the stage, leaving something behind or something that occupies something else [9].

The concept of a king deity is a concept that views the position of the king as the position of a god or the incarnation of a god. He has enormous power, supernatural power, and responsibility for mankind. This concept comes from the concept of Javanese Hinduism. According to Lekkerkerker, what is seen in the titles of kings such as Wisnu Wardhana is a title for Erlangga. After the arrival of Islam these titles changed to Islamic titles, such as khalifatullah, Sultan, and Sunan [11].

This concept is directed at the attitude of the people towards the king, where the king becomes the most feared person, is heard. Even in the context of Javanese society there is an attitude of worship that is revealed at the time of facing the king. The concept of king deity is a concept that originates from pre-Hindu-Buddhist cultural syncretism [11].

Furthermore, this concept was carried away and influential in Islamic culture which acculturated Javanese spiritual culture [12]. The concept appears in the ways of mentioning the king with titles that show the highest, the most powerful on earth such as the mention of "Gusti ingkang ratu" as the highest designation for the king who later called the call "Gusti". The concept of supreme mastery is seen in the mention of God, namely "Gusti Allah". In the mention, there seems to be a desire to put the king as the highest ruler in the world.

In the Serat Wulang P.B text. IX Pupuh 6 verse 11, there is a mention of the king with "Sampeyan Dalem ingkang Sinuhun Kanjeng Susuhunan Pakubuwana IX". From the text it can be seen that the mention of "sampeyan dalem" is the mention of the king. In the mention of the king of Java there is also the mention of "Ingkang Sinuhun Kanjeng Susuhunan Senopati ing Ngalaga Ngabdurrahman Sayidin Panatagama". The word "sayid" is a term for Arabs descended from the Prophet Muhammad [7]. "Susuhunan" is the term king of Surakarta, which means worship. Furthermore, the meaning and title are "the noble offerings of the senopati of war, Ngabdurrahman, which is the security of the Prophet Muhammad as a religious administrator".

The Javanese have the phrase "mengko sira genti ingsung" which means you will be my successor. This was later interpreted as "khalifah" [13]. The title "Susuhunan Panembahan 
Senopati ing Ngalaga Ngabdurrahman Sayidin Panatagama" is a title given to the king in Kasunanan Surakarta after the Giyanti agreement [14]. The title gives the meaning that in the Javanese sunan community or king is the khalifatullah fir ardi who is tasked to memayu hayuning bawana or the king has the duty to maintain the preservation of the earth as it is.

In the Surakarta Kasunanan Palace with the character of the Keraton Mataram Islam which is concentric, the position of the king or sunan is at the peak of the sacred hierarchy which creates harmony. Sunan in the view of traditional bureaucracy is the center of the world which occupies the top of the hierarchy of the palace community. In this case, sunan is the same as deity in Hindu and Buddhist mythology, therefore sunan is the same as deity. In the tradition of the Surakarta Keraton community, sunan is the head of state and government who concurrently heads of religion. Sunan is a judge and prosecutor, so the title used is "Sampeyan Dalem Ingkang Sinuhun Kanjeng Susuhunan Pakubuwana Senopati Ing Ngalaga Abdurrahman Sayidin Panatagama".

The meaning of the word sunan is the first person to be respected in the palace and sunan to be the center of world life. Another term is Pakubuwana. Besides that sunan is the supreme commander or senopati ing ngalaga and trustworthy bearer of the establishment of Islamic law or called sayid panatagama [14].

The position of such a high king in Javanese society shows that local wisdom was created by ancestors on earth. The nista madya utama is local wisdom directed at kings, leaders to overcome the natural problems of the Java problem.

\subsection{Nista Madya Utama and World Peace throughout Times}

Nista madya utama is local wisdom which was originally intended for kings and leaders. The king and the Javanese leader were expected to be able to practice the main concept of civil society. The king of Java was the king's god, who held the control of the people and nature. So the intelligence of the Javanese appears in the main moral doctrine of morality. This intelligence can be explained from the opinion that who controls the structure, it is he who regulates culture [15]. The culture expected from the main civil service concept is described as below.

\subsubsection{Memayu Hayuning Bawana}

If the leader has the attitude to be able to understand and carry out the concept of nista madya utama, then nature will be protected from damage and digital drunken conditions, so that harmony will occur in the world. The concept of nista madya utama contains the statement that humans are forbidden to do evil actions both in their religious life and social life. Nista actions in religious life are acts of humans who do not carry out their religious obligations, do not acknowledge their faith, and violate religious restrictions. For that humans are required to do virtue.

Utama actions is more than normal. More action on the spiritual life is an act of humans who are conscious of wanting to reach the love of God. For that ritual acts not only do the obligatory ones, but also all that are sunnah. Likewise, to be able to perform virtue, it is very good self-control. With self-control, humans do not slip into actions to harm others, use the rights of others even if only slightly, violate religious and social rules and are strong, firm and not shaken by temptation. The utama action is taken after humans can overcome the temptation to do evil and realize their responsibilities as God's creatures in the world, so they can divide their time to help others, social activities and environmental preservation. 
The description of the above virtues is given to the king or leader who has the carrying capacity of physical strength, knowledge, skills and economy, and the environment. However, it will be different if the king or leader has a deficiency in the carrying capacity. A king who lives in a socio-political situation and a work environment that does not support it will be difficult to take the utama action, so it is better to choose madya concept in leadership.

Likewise, if there are economic limitations, the utama actions related to the funds will be limited so that they will move in the madya concept area. While leaders who have limited ability, skill, and knowledge will be safer if they move in the madya concept area although it is possible that he will take the utama action in the utama concept in the field of funding.

Based on the description, the concept of a good leader is a leader who does not take action, preferring the madya concept and the utama one. Such a concept will be able to build memayu hayuning bawana or preserve nature and its soil. That is considering that the power of the Javanese kings, especially the kings of Islamic Mataram to their descendants, even the concept was understood by the Javanese community as the great binathara, which is of the great nature like a god.

The concept is also understood by the people when looking at leaders as owners of everything, both property and human beings. Therefore, against the king's wishes, the people will be able to answer "ndherek kersa dalem" or follow your will [16]. Such great power is said to be the authority of "wisesa ing sanagari", which means having the highest authority throughout the country [17]. In the world of great powers of power it is described as "gung binathara, bau dhendha nyahrawati" or as big as the power of a law-keeping deity and ruler of the world [17]. Therefore the main concept of mid-life for a king or leader will be able to make progress and world peace. Guarding in Javanese culture is called the term "memayu hayuning bawana". In this digital era, people think more individually, selfishly and use energy and materials that are not environmentally friendly. With this main concept of madya, leaders will be able to call for action with the nista madya utama local wisdom by acting first.

\subsubsection{Memayu Hayuning Kaluwarga}

The notion of memayu hayuning kaluwarga is to maintain security, peace and tranquility so that a family is created which in terms of Islam. A family that maintains calm, tranquility and peace between family members who are referred to as sakinah families. Furthermore, the families who are mawadah are families who love each other and love each other among their family members. Besides that there are also family terms that are Rahmah. Rahmah means forgiveness of mercy, sustenance, and grace. This means that families who get grace from God because the family is awake in love and trust [18].

\section{CONCLUSION}

The nista madya utama is a flexible concept applied. On the one hand it can be applied to leaders to their families or individuals. Therefore this concept is a concept of local wisdom which is the basis of the view to achieve a peaceful life. In memayu hayuning kaluwarga concept, family members should not act in contempt such as having an affair, not being straightforward between family members, ignoring love of family, not respecting other family members, not carrying out obligations, depriving other family members of their rights, envy and jealousy all of which will cause the family to feel uneasy that there will not be a family that is sure to be sakinah mawadah warahmah. In this case the head of the family cannot maintain the concept of memayu hayuning kaluwarga. 


\section{REFERENCES}

[1] G. Saksono, Politik Adu Domba dan Pecah Belah. Yogyakarta: Ampera Utama, 2019.

[2] P. . Zoetmulder, Kalangwan, Sastra Jawa Kuno Selayang Pandang. Jakarta: Djambatan, 1985.

[3] R. N. Ronggowarsito, Zaman Edan. Yogyakarta: Narasi-Pustaka Promethea, 2017.

[4] J. Danandjaja, Folklor Indonesia: Ilmu Gosip, Dongeng, dan Lain Lain. Jakarta: Pustaka Grafitipress, 2002.

[5] Poerbatjaraka, Kapustakan Djawi. Jakarta: Djambatan, 1964.

[6] S. Endraswara, Falsafah Hidup Jawa. Yogyakarta: Cakrawala, 2012.

[7] W. J. . Poerwadarminta, Baoesastra Djawa. Batavia: J.B. Wollters Uitgevers. Maatschappi, 1939.

[8] W. Widyawati, Etika Jawa, Menggali Kebijakan dan Keutamaan Demi Ketentraman Hidup Lahir Batin. Yogyakarta: Pura Pustaka Yogyakarta, 2012.

[9] S. H. Widyastuti, "Serat-Serat Wulang P.B. IX," Universitas Negeri Yogyakarta, Yogyakarta, 2019.

[10] A. Tedjowirawan, "Unsur-unsur Ajaran Pemimpin Negara dan Abdi Negara di dalam Teks-teks Pustakaraja Madya Karya R. Ng. Ranggawarsita, Relevansinya dengan Kepemimpinan Masa Sekarang,” Jurnal Humaniora, vol. XIII, no. 2, 2001.

[11] S. Isbodroni, "Faham Kekuasaan Jawa Pandangan Elit Kraton Surakarta dan Yogyakarta,” Universitas Indonesia, Jakarta, 2002.

[12] S. Imam, Konsep Tuhan, Manusia, Mistik dalam Berbagai Kebatinan Jawa. Jakarta: PT. Raja Grafindo Persada, 2005.

[13] R. Ricci, "Corvension to Islam on Java and the Book of One Thousand Question," Bijdragen tot de Taal-Land-en Volkenkunde, vol. 165, no. 1, 2009.

[14] Muslich, Moral Islam dalam Serat Piwulang Pakubuwana IV. Yogyakarta: Global Pustaka Utama, 2006.

[15] Sri Sultan Hamengku Buwono X, Sabda Ungkapan Hati Seorang Raja. Yogyakarta: PT. BP Kedaulatan Rakyat.

[16] Moedjanto, Konsep Kekuasaan Jawa; Penerapannya oleh Raja-Raja Mataram. Yogyakarta: Kanisius, 1987.

[17] S. Moertono, State and Statecraft in Old Java. Ithaca, 1968.

[18] K. Saddhono and S. Supeni. "The role of dutch colonialism in the political life of Mataram dynasty: A case study of the manuscript of Babad Tanah Jawi." Asian Soc. Sci. vol. 10 no. 15 pp. $1-7,2014$ 